\title{
The Maqasid Thought of Ibn 'Ashur and Development of Interdisciplinary Islamic Studies: Searching for the Correlation of the Concept
}

\author{
Mohamad Anang Firdaus ${ }^{1}$ \\ \{anangfirdausm@gmail.com ${ }^{1}$ \} \\ ${ }^{1}$ Ma'had Aly Hasyim Asy'ari-East Java- Indonesia
}

\begin{abstract}
Ibn 'Ashur is a figure of Islamic thinker who is widely known as an expert commentator and world Maqasid figure. However, his thinking about maqasid as an approach to Islamic studies has not received much attention from researchers and academics. The article tries to reveal the root and correlation between the Interdisciplinary Islamic studies with Maqasid thought of Ibn 'Ashur. This article is written as library research in which the author analyzes a thematic study of Maqasid as an approach to Islamic studies in four books written by Ibn 'Ashur, for Searching the correlation of the concept to answer the problems in this study, among others; al-Tahrir wa al-Tanwir; Maqasid al-shari'ah al-Islamiyyah, Alaysa al-Subh bi Qarib and Usul alNizam al-Ijtima'iy fi al-Islam. Meanwhile, secondary sources are taken from scientific books or journals that have the same topic of discussion as this research. This article finds a strong correlation between the Maqasid thoughts of Ibn 'Ashur with interdisciplinary Islamic studies, in which in his four books the science of Maqasid is used as an approach in Islamic studies on three themes, namely Maqasid science in tafsir studies, educational thought and social society.
\end{abstract}

Keywords: Maqasid Thought, Ibn ‘Ashur, Interdisciplinary of Islamic Studies

\section{Introduction}

Today, technological advances and the Covid 19 outbreak have directed Islamic studies to the need for an interdisciplinary approach in Islamic studies. The interdisciplinary approach provides opportunities for supporting sciences that can help understand Islam more comprehensively. This is because the development of technology and information has given new methods and approaches that are important to be used in answering problems that arise in the era of technology and information. The development of science and technology gave rise to several disciplines that were used as an approach to Islamic studies. The interdisciplinary Islamic studies introduced by Harun Nasution in Indonesia in the early 70s, at the beginning of its appearance, never ceased to be debated among Islamic intellectuals in Indonesia. This interdisciplinary approach has received a rejection from some groups of Islamic schoolars, because they thought that conventional Islamic studies will be abandoned, in addition to this kind of approach is considered to be damaging to student morals and beliefs, because this interdisciplinary approach is closely related to value-free studies and does not have a strong epistemological foundation in Islamic teachings.

Interdisciplinary Islamic studies have been introduced by scholars in modern times, one of which is Ibn 'Ashur. The thoughts of this Tunisian Shaikh in many of his works use an Interdisciplinary approach based on his maqasid thinking. Ibn 'Ashur also encourages the Islamic world to use Western modern science if there is a benefit for Muslims. Ibn 'Ashur is a 
figure of Islamic thinker who is widely known as an expert commentator and interpretator, and also a maqasid thinker in the world. However, his maqasid thought as an approach to Interdisciplinary of Islamic studies has not received much attention from researchers and academics. Apart from that, the old paradigm of Islamic education which did not accept criticism was also a concern of Ibn 'Ashur. He said that this was one of the factors for the decline in education in the Arab world. A conservative shifting paradigm to a new paradigm was attempted by Ibn 'Ashur. Although the study of maqasid is generally included in the discipline of shari'ah, Abdurrahman al-Nahlawi said that maqasid thought could enter into a broader study.[1] Al-Nahlawi considered that maqasid thought had a close relationship with educational studies, so that education has an orientation to create benefit (maslahah).[2] This article seeks to find the correlation between the thoughts of maqasid Ibn 'Ashur with interdisciplinary Islamic studies.

Looking at the above problems, the focus of this research is directed at: (1) How is the thought of Ibn 'Ashur and his contribution in developing maqasid science? (2) How is the maqasid thought of Ibn 'Ashur as an approach in interdisciplinary Islamic studies? and (3) What are the factors that shape the maqasid thought of Ibn 'Ashur?

Theoretically, this research can provide a discourse on the genealogy of thought in interdisciplinary Islamic studies and its relationship with maqasid thinking in Islamic studies. In practical terms, it has implications for changing the perspective on the concept of Western education which is assumed to be value-free and does not have strong epistemological roots from the al-Qur'an by some observers of Islamic education. Despite the fact, Islamic education itself was developed by adopting the concept of Western education for the last few decades. In addition, the maqasidi education paradigm can theoretically also bridge the Islamic education thought with the concept of Western education following the spirit of alQur'an in the perspective of maqasid Ibn 'Ashur.

\section{Method}

This article is written as library research in which the author analyzes a thematic study of maqasid as an approach to Islamic studies in four books written by Ibn 'Ashur, for Searching the correlation of the concept to answer the problems in this study. The primary sources in this study are four books by Imam al-Tahir Ibn 'Ashur, among others; al-Tahrir wa al-Tanwir; Maqasid al-shari 'ah al-Islamiyyah, Alaisa al-Subh bi Qarib and Usul al-Nizam al-Ijtima'iy fi al-Islam. Meanwhile, secondary sources are taken from scientific books or journals that have the same topic of discussion as this research.

Research on maqasid thought of Ibn 'Ashur and Islamic studies have been carried out either directly or indirectly. First 'Aishah binti' Amir ibn 'Uwaimir al-Sufyani. Al-Fikr alMaqasid $i$ wa Atharuhu fi Bina 'al-Nazariyyah al-Tarbawiyyah al-Islamiyyah. Doctoral Dissertation of Umm al-Qura University Saudi Arabia. This research concludes that maqasid thinking acts as a methodological instrument that can be used to transform maqasid from a theoretical realm to a practical realm.[3] Muhammad al-Tahir al-Misawi. "Al-Shaikh Muhammad al-Tahir Ibn 'Ashur wa Qadaya al-Islah wa al-Tajdid fi al-Fikr al-Isla mi alMu'asir: Ru'yah Ma'rifiyyah wa Manhajiyyah" published in the journal al-Tajdid. Al-Misawi reviews the science of maqasid as explained by Ibn "Ashur has a position as a philosophy of Islamic law. This is one of the reasons why Ibn 'Ashur made the science of maqasid an independent science, which is independent from the science of usul, as well as the thought of maqasid ibn' Ashur on the social aspect of society as a system in helping the world civilization "al-'Umrani".[4] NajiFaraj al-Takuri. "Malamih al-Islah al-Tarbawi fi Tafsir Ibn 
'Ashur" in the Journal Usul al-Din. This study concludes that the Qur'an has contained a complete educational concept, which is in tune with the times across generations.[5] In addition there is Abd al-Lawi Bashir Makkiy. "Ishkaliyyah Islah al-Ta'lim Min Khilal Alaysa al-Subh bi Qarib li Muhammad al-Tahir Ibn "Ashur" Which discusses the thought of educational reform (al-Islah al-Tarbawiy) Ibn 'Ashur as stated in his book Alaysa al-Subh bi Qarib, then contextualizes these ideas today.[6] This article would be focus to attempts reveal the correlation between the concept of maqasid Ibn 'Ashur's thoughts with interdisciplinary Islamic studies.

\section{Result and Discussion}

\subsection{Ibn 'Ashur in the History of the Development of Maqasid Thought}

As a scientific discipline in general, a science develops after passing through several phases, starting from the period of formation to reaching the contemporary period, so the science of Maqasid al-shari' 'ah also undergoes this development process. Maqasid al-shari ' $a$ h is not born from a vacuum suddenly, it goes through several phases of development until finally it becomes an independent discipline and becomes a new approach. The Maqasid can be the root of interdisciplinary of Islamic studies, because interdisciplinary in Islamic studies is actually has been done by the previous or classic Islamic scholars. This section will describe the position of Ibn 'Ashur in the history of the thought of the maqasid scholars since its beginnings.

The period of development of the science of maqasid can be divided into two phases; the pre-codification phase, and the codification phase. The pre-codification phase includes the development of maqasid during the Rasulullah, al-Khulafa' al-Rashidin, Tabi'in, and Imam Madhahib. While the codification phase covers the era of the scholars of the fifth-century hijriyah which began with the beginning of the concept of maqasid al-shari'ah which theoretically was in the golden age in the 3rd to the 5th century A.D. This was marked by the term "maqasid "towards the end of the 3rd century. ${ }^{1}$ The word maqasid is written in the first manuscript which is directly used as the title of the book, namely al-Salat wa Maqasid uha by al-Tirmidhi al-Hakim until modern times.

In the next generation from the initial phase of codification, several scholars appeared who had discussed maqasid theory in the 3rd to 5th centuries, such as al-Hakim al-Tirmidhi, Abu Zaid al-Balkhi, Abu Bakr Muhammad al-Qaffal, Abu Bakr al-Abhary, al-'Amiry, and Abu Bakr ibn al-Baqilani who began discussing the reasons and wisdom behind the shari' $a h$ law so that the rules made by Allah can be reached by human reason.

The codification period in the middle phase was marked by the development of Maqasid theory, especially in the 5th century AH, with al-Juwainy ${ }^{2}$ (d. $478 \mathrm{H}$ ) and al-Ghazaly ${ }^{3}$ (d. 505

\footnotetext{
${ }^{1}$ However, if we trace some primary literature written before the 3 rd century, we will find a substantive discussion of maqasid even though it has not referred to the established maqasid science. Imam Malik (d. $179 \mathrm{H}$ ) in the book "Al-Muwatta" has written a history which refers to the case of using maqasid at the time of the companions. The use of the word maqasid is also followed by Imam Shafi'iy (w. 204 H) in the book "Al-Risalah" which alludes to the discussion ta'lil al-ahkam (excuse search in a law), some maqasid kulliyyah such as hifd al-nafs and hifd al-mal. The theme of this discussion then becomes the emryo of themes in maqasid science.

${ }^{2}$ Al-Juwainy is also popular with the name al-Imam al-Haramain, famous as the originator of the theory of 'public needs'. Look: Jasser Auda, al-Maqașid for Beginners...., 38. Maqașidy Al-Juwainy's reasoning can be read in his book al-Burhān fì Ușūl al-Fiqh and Giyāth al-Umam.
} 
$\mathrm{H})$ as the most influential figures. Unlike in the initial phase of codification, where the science of maqasid is still substantive in the science of usul, in this middle phase the basic theory and foundations that are universal (al-usul al-kulliyyah) Maqasid scientifically. At this time Maqasid al-Qur'an (the aim of the quran) has been conceptualized. However, the Maqasid alQur'an which was described by the scholars of the era in this early phase who were still in a certain scientific discipline, such as tasawuf or the science of tafsir.

Imam al-Haramain al-Juwainy $(\mathrm{d} .478 \mathrm{H})$ al-Ghazaly $(\mathrm{d} .505 \mathrm{H})$ which discusses the method of knowing maqasid. Then the theory of maqasid continued to be developed by the next generation of scholars, such as Fakhr al-Din al-Razy, Al-Amiddy, al-'Izz Abd al-Salam and several scholars afterward until it arrived in the golden age of maqasid knowledge in the hands of al-Shatiby. In the hands of al-Shatiby (w. $790 \mathrm{H})$ maqasid al-shari'ah reached the peak of maturity through his book entitled al-Muwāfaqāt fì Ușūl al-sharì'ah, which means Harmonization of Shari 'ah Principles. After the period of al-Shatiby maqasid al-sharíah experienced stagnation until finally in the modern era al-Muwāfaqāt al-Shatiby was again printed for the first time in Tunisia (1301 H / 1884 AD ).

In this era, there was an intensive dialectic between modern ulama and al-Muwafaqat, so that maqasid al-shari'ah figures emerged. One of them is Muhammad al-Tahir Ibn 'Ashur (w. 1393 H / 1973 AD) with his monumental book Maqasid al-shari'ah al-Islamiyyah. It was he who was later dubbed the "Father of Contemporary Maqasid". The existence of Ibn "Ashur with its contribution to the development of Maqasid thought encouraged the emergence of maqasid figures in the contemporary era. It is the influence of Ibn 'Ashur's work of maqasid in the interdisciplinary of Islamic studies in the contemporary time, because many modern scholars are referring most on the maqasid of Ibn 'Ashur, such as 'Allal al-Fasi, Jamaluddin 'Atiyyah, Jasser Auda or al-Raisuni who try to make a transdisciplinary dialogue on maqasid science with other scientific groups, as well as linking with contemporary global issues.

\subsection{Thought of Ibn 'Ashur and His Contribution to Developing Maqasid Science}

\section{Reintroducing the Study of Maqasid al-shari'ah after the Stagnation Period}

In the study of maqasid, Ibn 'Ashur had a strong influence in the process of his development. For example, the renewal he did in maqasid. Ibn 'A shur has reintroduced the thought of maqasid after a period of stagnation for six centuries $(790 \mathrm{H}-1393 \mathrm{H})$ after the death of al-Shatiby. Substantially, maqasid al-shari'ah has been known as a paradigm of Islamic law since Islam began to exist with its shari 'ah law. However, in terms of scientific concepts, the thought of maqasid al-shari'ah has just been systematically awakened as a discipline in the hands of al-Shatiby $(\mathrm{d} .790 \mathrm{H})$ through his book al-Muwāfaqāt fì Ușūl alsyari 'ah. This achievement made al-Shatiby known to the world as the first father of maqasid al-shari'ah.

Meanwhile, Ibn 'Ashur, through his book maqasid al-shari'ah al-Islāmiyyah, has succeeded in developing maqasid by perfecting the concept of maqasid al-shari 'ah belonging to al-Shatiby. Furthermore, Ibn 'Ashur even made maqasid al-shari'ah as an independent discipline. For the services of developing the maqasid knowledge, Ibn 'Ashur was then

\footnotetext{
3 Al-Ghazali is a student of Al-Juwainy. In the hands of al-Ghazali emerged the "five levels of inevitability" (al-darūriyyāt al-khamsah), namely hifz al-dīn (the preservation of religion/faith), hifž alnafs (the preservation of life), hifz al-'aql (the preservation of intellect), hifz al-nasl (the preservation of life age), and hifz al-māl (the preservation of wealth). More complete views of al-Ghazaly on this matter can be read in his book al-Mustașfā.
} 
dubbed the "second teacher" (al-mu'allim al-sian $\vec{\imath}$ ) after al-Shatiby who received the title of "the first teacher". ${ }^{4}$ [7] The title is not just an expression of hyperbole and making it up. Because after al-Shatiby appeared with its concept, maqasid al-shari'ah thought had been stagnant for a long time, the stagnation lasted for about six centuries $(790 \mathrm{H}-1393 \mathrm{H})$, until finally, it appeared Ibn' Ashur.

In the hands of Ibn 'Ashur, the concept of maqasid al-shari'ah became more universal. The scope of maqasid with the concept of Maqasid 'Ammah Ibn' Ashur makes the discourse of Maqasid studies broader. Also, with the concept of Maqasid Khassah it also draws the study of maqasid into a more detailed section. This concept is one of Ibn 'Ashur's original thoughts that had not been encountered before. The classification made by Ibn 'Ashur on maqasid al-shari'ah into Maqasid 'Ammah and Maqasid Khassah' brings maqasid knowledge to in an advanced stage in the study of Islamic thought.

Ibn 'Ashur contributed to the development of the theory of maqasid al-shari' ah which was previously limited in the scope of kulliyah ${ }^{6}$ and juz'iyyah ${ }^{7}$ to be more holistic, by widening the scope of the concept of maqasid al-shari 'ah into a more specific realm that deals with the subject of a special sub-discussion of Islamic law (maqasid al-shari 'ah al-khāsșah). ${ }^{8}$

\section{Developing Maqasid al-Shari'ah to Becomes More Holistic (Universal-Partial)}

From the aspect of coverage and enforceability, maqas|id 'ammah which is universal, in the sense that this goal is not specific to Muslims, but this concept can also be applied to humans and the universe as a whole. In Ibn 'Ashur the universality of shari'ah can be accepted by humans as a whole. Apart from that, Islamic shari'ah was also sent down to establish a system of life-based on the substance of Islamic shari ' $a$ h in the form of the order of life of society on earth.[8] The most important point of the concept of universality of shari 'ah Islam Ibn' Ashur is focused on the goals to be realized through the implementation of shari 'ah Islam, namely the creation of benefits in human life anytime and anywhere.

The universality of shari'ah Islam in Ibn 'Ashur's view is not positioned as an achievement target of shari'ah, but rather it is positioned as a way of implementing maqasid

${ }^{4}$ As Jaser Audah's assessment concluded that al-Shatiby through the book al-Muwāfaqāt fì Ușūl alshari'ah, has succeeded in producing three important transformation formulas in the construction of the theory of al-maqāsșid that have not been carried out by maqasid scholars previous id. First, maqāșid from just maslahat apart from the source of tashri '(al-mașālih al-mursalah) becomes the basis of religion, the rules of shari' ah and the main points of belief in Islam (ușül al-dīn wa qawä'id alshari'ah wa kulliyāt al-millah). Second, the maqāșid which was originally a 'wisdom behind the rules' becomes a 'basic rule'. So any legal provisions made in the name of shari 'ah must be maqāsid oriented. Third, maqāșid which was originally understood as 'conjecture' (zanniy) becomes a 'belief' (qat'iy) through the process of induction of the verses of al-Qur'an to draw conclusions about maqāșid.

5 The maqasid khassah contains several chapters of partial Islamic law, such as muamalah law and family law. In the discussion of maqas |id khassah, this is the concept of al-Usul al-Khamsah which will directly intersect. The thought of Ibn 'Ashur about the concept of maqas |id khassah which is associated with al-Usul al-Khamsah emphasizes the maintenance of individual benefit and is limited to the harm of Muslims. The stiff is narrower than maqasid 'ammah.

${ }^{6}$ Maqasid al-shari 'ah which is formulated from religious texts relating to the main objectives of religion globally.

${ }^{7}$ Maqasid al-shari'ah which is formulated from a religious text which deals with partially religious purposes.

${ }^{8}$ For example about mu'a malat which is studied in the perspective of maqasid al-shari 'ah, for example maqasid al-shari'ah the law of criminal law, maqasid al-shari 'ah family and so on. 
shari 'ah so that in its technical realm, it can truly beneficial for all humans, both Muslims and non-Muslims. This universal benefit can be seen from the concept of al-Samahah (convenience) in the teachings of Islam (shari'ah), in which all humans regardless of their religion will gravitate towards this characteristic.

\section{Making Maqasid Studies as Independent Science}

After the old age of maqasid thinking, Ibn 'Ashur has dynamized and developed the concept of Maqasid al-shari'ah al-Shatiby. Until making it an independent scientific discipline. This is because Ibn 'Ashur believes that all the laws of shari'ah must contain the aims and objectives of Shari 'in the form of wisdom, benefit and benefits.[9] At the macro level, the law of shari 'ah contains a global goal, which is to maintain the order of the people and perpetuate the benefit for them.[10]

\subsection{The Correlation Between Maqasid Thought of Ibn 'Ashur and the Interdisciplinary Islamic Studies}

In all studies of Islamic thought, Ibn 'Ashur uses the science of maqasid as the basis for his theory. As can be found in Ibn 'Ashur's thoughts in his various books, such as al-Tahrir wa al-Tanwir (interpretation sector), Usul al-Nizam al-Ijtima 'iy fi al-Islam (social sector) and Alaysa al-Subh bi Qarib (education sector). Ibn 'Ashur explained Islamic thought in the field of interpretation, social society and education in the perspective of maqasid science based on his four very popular maqasid principles, namely al-Fitrah, al-Samahah, al-Musawah and alHurriyyah. And also based on al-Maqasid al-A'la in al-Qur'an which includes al-Salah alFardiy (Individual Piety), al-Salah al-Jama 'iy (Social Piety) and al-Salah al-'Umraniy (Piety of Civilization). Until finally this thought of Ibn 'Ashur gave the next generation a new perspective on maqasid science. Like Jasser Auda who made maqasid knowledge as a new approach in the study of fiqh, or Abdullah Saeed with his maqasid $i$ interpretation.

We will describe the maqasid side contained in Ibn 'Ashur's thoughts in the field of tafsir, social and educational studies. Such thinking will pave the way for interdisciplinarity in Islamic studies.

\section{Maqasid Science in Tafsir Studies}

Ibn 'Ashur made this commentary book as a medium of expression of his ideas in scientific discourse in the field of tafsir studies which had not been widely discussed by predecessor scholars. In the book al-Tahrir wa al-Tanwir, Ibn 'Ashur emphasizes that the book al-Tahrir wa al-Tanwir answers the problem of negative stigma in the bi al-Ra' $y i$ interpretation. He clarified that not all rational interpretations are categorized as despicable interpretations. If all that is based on reason is despicable, then of course many of the words of friends and practitioners will be rejected. In fact, they actively interpret the Qur'an, both adhering to the Sunnah of the Prophet and the results of their own ijtihad. The word "al-ra' $y u$ " according to Ibn 'Ashur is a word that still has a general meaning that requires details in the explanation of its meaning. Although there are the hadith of the Prophet which prohibit interpretation with reason, according to Ibn "Ashur the word " $a l-r a$ ' $y u$ " in interpretation is not 
what is meant in the hadith. ${ }^{9}$ [11] If in interpretation a person uses his intellect accompanied by a set of scholarships in the method of interpretation then this is not a problem for Ibn 'Ashur. On the other hand, Ibn 'Ashur also criticizes the opinion that the best interpretation is based on the history of the Prophet.

In Ibn 'Ashur's view, there are three paths taken by the mufassir in an attempt to interpret al-Qur'an. The three paths are: First, stop at the textual meaning of al-Qur'an. Through analysis on the linguistic aspect, a mufassir tries to explore the meaning in a text of al-Qur'an. Second, trying to explore the text of al-Qur'an into several religious disciplines, such as aqidah, fiqh, morals and others. Third, positioning the scientific discipline as an interpretive approach in finding wisdom and purpose (maqasid) of the al-Qur'an text.[12]

In the technical expression of maqasid in the text of al-Qur'an, Ibn 'Ashur predominantly uses al-Qur'an linguistic studies. Apart from lafadz analysis in the aspect of $i^{\prime} r a b$ is also a concern in interpretation as a medium for interpreting the text of al-Qur'an to explore the meaning and maqasid (objective) of the text.[13] In addition to confirming the validity of the $b i$ al-Ra'yi interpretation and using an exegetical methodology based on maqasid, through the book al-Tahrir wa al-Tanwir Ibn 'Ashur also set the objectives of alQur'an was revealed (Maqasid al-Qur'an) which is explained in the preamble of its interpretation that Maqasid al-Qur'an is a theory that must be understood by the interpreter in the process of al-Qur'an interpreting.[14]

\section{Maqasid Science in Educational Thought}

The maqasid thoughts of Ibn 'Ashur in the aspect of education are recorded in his book Alaysa al-Subh bi Qarib. This work has a very strong maqasid nuance in looking at the education system. He criticized the education system adopted in the Islamic world. $\mathrm{He}$ considers that the system cannot lead to the progress of the nation. This is because the education of the Islamic world maintains a conservative, intellectualist-literalistic method, without any purpose (maqasid) behind it. In addition, Ibn 'Ashur wants to change the conservative teaching system towards education that adopts the advances that have occurred in modern times. And science should be able to tangibly intersect with social conditions.

Belqasim Al-Ghali explains that in Ibn 'Ashur's point of view, the decline of Islamic education that occurred at Zaytunah University now occurs because the figures remain in the conservative education system with unclear teaching systems and learning curricula in it. They seem to close their eyes to some of the new methods born out of the progress of the times. Besides, there is still a discourse on the dichotomy of religious and general knowledge which also makes a negative contribution to education stagnation in the Islamic world. So that philosophy, mantiq and science do not get a place in madrassas and universities in Tunisia.[15]

Paradigmatic problems in education regarding philosophy and methodology have been accommodated in the concept of Hurriyyah (freedom) which is one of the four basic principles of maqasid ${ }^{10}$ in the concept of Ibn "Ashur. Hurriyyah is divided into four parts, ${ }^{11}$ one of

\footnotetext{
${ }^{9}$ Responding to the prohibited traditions above, Ibn 'Ashur argues that al-ra' $y u$ has an understanding as a word that comes from the heart without paying attention to the arguments, both from the aspect of language and the purpose of syllable. Likewise, they do not see the rules in the knowledge of alQur'an, for example, asbab al-nuzul, nasikh mansukh and others.

10 The four basic principles of maqasid Ibn 'Ashur, namely al-fitrah (religious instinct), al-samahah (tolerance), al-musawa $h$ (egalitarian) and al-hurriyyah (freedom of action). These four basic
} 
which is directly related to education, namely Hurriyyah al-Aqwal (freedom of opinion) which also implies freedom to study knowledge (Hurriyyah al-'Ilm), freedom of teaching (Hurriyyah al-Ta'lim), and freedom of writing (Hurriyyah al-Ta'lif). [14] In another of us, namely Usul al-Nizam al-Ijtima'iy fi al-Islam, Ibn' Ashu r also adds the concept of hurriyyah al-fikr, which is freedom of thought outside of matters of religious belief. Freedom of thought here includes matters related to reasoning, such as thinking about scientific opinions, deepening shari'ah, management and governance, and several matters relating to everyday life.[17]

Freedom in this scientific matter guarantees a person to study science without any limitations and scientific dichotomy. Likewise in teaching and writing. This freedom has led to progress in the history of Islamic education. Until the emergence of various schools of figh and schools of $\mathrm{ilm}$ kalam. This freedom has also succeeded in creating a high academic atmosphere among Muslims, resulting in various kinds of research, innovation, and experimentation in various fields of science, such as medicine, mathematics, physics, robotics, and so on. Until ushering in Islam in its golden age.

\section{Maqasid Science in Social Society}

The thought of maqasid in the social aspect is outlined by Ibn 'Ashur in his book Usul al-Nizam al-Ijtima 'iy fi al-Islam. As the book Alaysa al-Subh bi Qarib and al-Tahrir wa alTanwir, and Usul al-Nizam al-Ijtima'iy fi al -Islam also uses the four basic principles of maqasid Ibn 'Ashur as a foundation in building the concept of benefit in the social context. As the goal to be achieved (maqasid) of religion to improve the situation (islah), in the book Usul al-Nizam Ibn 'Ashur divides it into two main parts, namely al-Islah al-Fardiy (individual improvement) and al-Islah al-Ijtima 'iy (community improvement).

In his introduction, Ibn 'Ashur explains more about the role of religion to improve the condition of a people which in this case is the subject of change by al-Qur'an. The purpose of religion in social improvement is as explained by Ibn 'Ashur:

"And there is no doubt that the true role of religion is to improve the conditions of the people (Islah al-Qaum) in which they has the obligation to carry it out. Religion also plays a role in removing society from the valley of decline to a higher state, whether it has a little or a lot of impacts, in accordance with Allah's will through religion, and also society is obliged to do so according to the wisdom of Him. And how many divine religions have someone who serves to strengthen the good side of humanity and form a good community?. So that with the goodness of each individual and community, global goodness can also be achieved (Salah al-Majmu'Kullihi) within the specified time limit.[18]

If we look at the two important parts of the book Usul al-Nizam al-Ijtima iy fi al-Islam which is the goal to be achieved through the role of religion, namely al-Islah al-Fardiy (individual improvement) and al-Islah al-Ijtima'iy (community improvement) are actually both following the highest goal (al-Maqasid al-A'la) which al-Qur'an. As stated by Ibn 'A shur in the introduction to his four books Tafsir al-Tahrir wa al-Tanwir.[19] Which is where Allah sent down al-Qur'an with the aim of explaining some of the things that support the

principles are also in line with human nature which makes the concept of maqasid al-Shari 'ah relevant to human needs and problems as a human.

${ }^{11} \mathrm{Ibn}$ 'Ashu r divides the concept of al-Hurriyyah into four parts, first Hurriyyah al-I'tiqad (freedom in belief), Hurriyyah al-Aqwal (freedom of expression), Hurriyyah al-Af'a $l$ (freedom of action), Hurriyyah al-Ka 'inah (freedom of others). 
maintenance of the objectives of the teachings of Islam itself which are divided into three objectives, namely: al-Salah al-Fardiy (Individual Piety), al-Salah al-Jama iy (Social/ Communal Piety) and al-Salah al-'Umraniy (Piety of Civilization). As for the global piety (Salah al-Majmu' Kullihi) as stated in the quote from Ibn' Ashur's opinion above (the combined goodness between individual and community goodness) is very relevant to the concept of al-Salah al-'Umraniy (the concept of goodness in civilization) in al-Maqasid alA'la in al-Qur'an.

The three general goals of the reduction of al-Qur'an (al-Maqasid al-A'la) can also be found in the concept of improving education (Islah al-Ta'lim) initiated by Ibn 'Ashur in his book Alaysa al-Subh bi Qarib. In which the concept of maqasid based on maslahah is explicitly conveyed by Ibn "Ashur in his introduction. That the final goal to be achieved from the learning process is the benefit of the knowledge obtained by a student both in this world and in the hereafter.[20] When viewed from the perspective of Maqasid al-Qur'an, this goal has relevance to the first goal of al-Maqasid al-A'la, namely al-Salah al-Fardiy (Piety Individual). In addition, the purpose of learning is also to produce leaders of the people both in the world and the hereafter.[21]

As for al-Maqasid al-A'la then al-Salah al-Jama iy (Social Piety) Ibn 'Ashur said that education is in the secondary level (al-Hajjiyah) has a function to know and fulfill the needs of social life (Hajjah al-Hayah al-Ijtima 'iyyah). Meanwhile, al-Salah al-'Umraniy (Piety of Civilization) is reflected in the aim of education in advancing human civilization (Taqaddum al-Hadarah) by realizing individual and social benefit.[22] All of these educational goals can be done with the condition that the education system must be improved first. And all education activists are aware of the general goals that should be achieved from an educational process.[23]

The explanation above is sufficient to prove that the concept of maqasid has been made by Ibn 'Ashur as a basic theory in his thinking in various fields of study, in this case, the science of interpretation, social science, and education. What has been done by Ibn 'Ashur by making maqasid science as the main basis in various Islamic studies is an important contribution in the development of maqasid science in the future. Until now, maqasid science has been used as a new approach in Islamic studies.

If the thoughts of maqasid Ibn 'Ashur above are measured using Amin Abdullah's theory, then we find that the thoughts of maqasid Ibn' Ashur can be classified into an interconnected entity model, namely the building of knowledge, each of which is aware of its limitations in solving human problems, then at least collaborates. in matters that touch the issue of approach (approach) and methods of thinking and research (process and procedure). Not an isolated entity model, it means that each knowledge group is independent, knows the existence of other knowledge clumps but does not touch and greet them methodologically.[24] Because in his frame of mind, Ibn 'Ashur seems to always use the maqasid as an approach in several scientific fields, such as exegesis, education and social sciences.

In building thoughts in some Islamic scholarship, Ibn 'Ashur always puts it on the foundation of four fundamental values of maqasid thought, namely al-fitrah, al-hurriyyah, alsamahah, and al-musawah. This is how maqasid thought to be used as an approach. From this, the seeds of interdisciplinary Islamic studies emerged. The dominance of the Bayani mindset which is textual-ijtihadiyyah makes the Islamic religious epistemology system which in Amin Abdullah's view is considered to be less concerned with religious issues,[25] made Ibn 'Ashur more dynamic by adding the contextualist side that exists in maqasid thinking. If Muhammad Azar mentions Islamic Studies as in the second period (1951-1975), he has started to get 
acquainted even though they are still running separately or there is no dialectic between areas of science with the areas of humanities, social sciences and natural sciences.

If we look at the thoughts of maqasid Ibn 'Ashur in some of his works with a maqasidi style, then actually Ibn' Ashur with the Maqasid science approach has made Islamic Studies a dialogue with the areas of humanities, social sciences and natural sciences. This is actually what Azar called the development of Islamic Studies in the third period (1976-1995), which states that the Islamic Studies area developed into eight areas - 'Ulum ad-Din, fiqh, and others - where this third period is also referred to as era of auxiliary sciences. Then in the fourth period (1996-present) the core sciencies of Islamic Studies, in which the eight fields have begun to dialectic with the areas of science and technology (al-'ulum al-kauniyyah/natural sciences) and other areas of study (humanities and social sciences).

This is an important contribution of Ibn 'Ashur in the development of maqasid thought in the realm of Islamic studies, namely making maqasid an independent scholarship. Thus maqasid science can be used as an approach in Islamic studies that will encourage dialectics between scientific families in Islamic studies. So that the thought of maqasid has contributed to the birth of interdisciplinary studies in Islamic studies. So it is fitting that Ibn 'Ashur is said to be "mu'allim thani", or the second father of maqasid science after al-Shatibi.

\subsection{Factors Affecting Ibn 'Ashur's Thought}

Ibn 'Ashur lived at a time when Muslims were in a decline of their civilization. Almost all Islamic countries are behind Western countries in terms of advances in science and technology. This then has an impact on the economic, social, and military sectors. In the end, the fall of the Islamic Caliphate was the culmination of all. Therefore, the spirit of reform that was born from the thoughts of several reformist figures gave birth to reform movements from the east and west. The renewal movement called on Ibn 'Ashur to take a real role. There are at least several contributing factors in shaping the thought of islah Ibn 'Ashur, which can be grouped into three main factors, namely; First, the personal factor. Second, the environmental factor which was formed by the Muslim reformist movement and the nationalism movement against French colonialism, and third, the external factor, from the opening of the horizons of progress achieved by the European world. The following will describe these three factors:

\section{Personal Factors}

In the history of his life, Ibn "Ashur has played a role as a student and lecturer at Zaytunah Universitywell. He then understood closely the problems and weaknesses he encountered. Then his conscience prompted him to think about the path of educational reform. What he thought about his ideas and views on education, then he poured it into his book Alaysa al-Subh bi Qarib. he then applies the idea of "islah" (reform) in many of his career responsibilities, both in the form of academic responsibility and administrative duties if the task is under his reformist thinking. Until finally Ibn 'Ashur concluded that educational reform is the foundation upon which all reform efforts are built in all aspects that are needed by a nation. Because of that, he felt relieved by leaving the doubt and accepting the task of driving the truth as required by the responsibility that humans carry as the leader of "khilafah" on earth.[26] 


\section{Environmental factor}

Ibn 'Ashur found the momentum to prepare for the reforms which he initiated to be a supportive environment and place. This can be seen from the opportunities he got through interactions with several teachers who had the spirit of reform, such as Salim Buhajib who had campaigned for the movement out of stagnant, as well as the view of the relevance of the demands of the times and the concept of maqasid al-shari' 'ah.

Support for the conditions that shape Ibn 'Ashur's reformist thinking can also be seen from the existence of several reformist discourses carried out by some reformist politicians, such as the establishment of a military school which was initiated by Ahmad Bay in 1840 AD, which contains all modern scholarship. Which has also contributed to the Tunisian people to turn their attention to the international world. As well as a series of reformist policies that have been made by Ahmad Bay which touch on learning activities at Zaytunah University, such as limiting the number of courses and teaching staff, as well as matters related to it.[27] Then the Sadiqiyyah madrasah was founded in 1875 AD, then the Khalduniyyah University was founded in $1896 \mathrm{AD}$, to complement the existing education at Zaytunah University. All these have shaped and encouraged Ibn 'Ashur's reform thinking. There were two main factors that formed a conducive environment for the development of Ibn 'Ashur's ideas of reform and renewal, namely: the influence of the Muslim reformist movement and the movement against French colonialism.

\section{External factors}

First, the influence of Muhammad 'Abduh, an Islamic reformer from Egypt. The idea is about "Islamic reform discourse" which is regularly campaigned through the magazine "al'Urwah al-Wutsqa". This magazine had a profound influence on the mindset of Tunisian scholars, including Ibn 'Ashur. This influence strengthened after the second visit of 'Abduh to Tunisia in 1903 AD' Abduh succeeded in stimulating the spirit of the Tunisian clerics and encouraging the birth of ideas of renewal. This is why Ibn 'Ashur is said to be influenced by' Abduh in addition to al-Afghaniand Rashid Rida.

Second, the influence from within Tunisia itself. The reform movement echoed by Khairudin al-Tunisiy has become a model and role model for every Tunisian scholar who has dreams of reform. Khairudin al-Tunisiy tried to increase intellectual spirit through strengthening the press and thinking. The strengthening included the massive printing and distribution of several classical books in several areas. Among the books that have priority is al-Muwafaqat. This book was printed for the first time in Tunisia and became a study material for scholars and students. In addition, Khairudin al-Tunisiy made a great effort to awaken Muslims from their adulthood and encouraged religious leaders to start looking at models of progress in European countries through his work entitled: "Aqwam al-Masalik fi Ma'rifati alAhwal al-Mamalik". The progress that has been achieved by European countries should be used as a reference in certain aspects.

In the reform efforts carried out in Tunisia, Khairuddin made several strategic policies that could inspire young intellectuals at that time. These strategic policies include: (1) Encouraging a reform movement aimed at publishers to reform public thinking through journalism. (2) Spread the idea of reform and the liberation movement through writings and articles in various magazines and other print media, as well as printing books at low prices for distribution to the public. (3) Enhancing the intellectual and scientific development of modern 
society by establishing two large universities with a modern system, namely al-Khalduniyyah and al-Shadiqiyyah.

The third is the awareness of influential figures and scholars to reform the education system. awareness of the importance of education which will have a major influence on the progress of a nation has spread among scholars and students. At that time, the attention of maqasid Ibn 'Ashur for the first time was seen in his book, Alaysa al-Subh bi Qarib, which contained constructive criticism through the eyes of maqasid on the education system in Tunisia and the Arab world at large.

Besides, the thoughts of many reformist figures have also influenced the movement of the reform movement that has taken place in Tunisia. Tunisia is one of the countries they have visited to spread ideas of reform as well as to discuss and exchange ideas with some Tunisian reformers. The most prominent of these reformers were Muhammad 'Abduh, Shakib Arsalan (1287-1366 H / 1869-1946 AD), 'Abd al-Hamid Ibn Badis (1309-1360 H / 1889-1940 M), and Muhammad al-Hajawi.[28]

In addition, Ibn 'Ashur observes the changes that education in Egypt brings through the newspapers. He also observed directly the thoughts of Muhammad 'Abduh when he visited Tunisia in $1320 \mathrm{H} / 1902 \mathrm{AD}$, who was describing the facts of the ongoing education. Besides, 'Abduh also criticized the teaching method, which may have turned the ears of conservative figures. from among the teaching staff. But actually 'Abduh reminded them of their closed eyes so that they understood the shortcomings that existed after explaining to them the results of reform in Egypt so that the madrasa students became more fluent orally and more profound scientifically than al-Azhar students. whose characters are still untouched by renewal.[29]

Fourth, Apart from Abduh, Ibn Khaldun's thoughts were very dominant in coloring Ibn 'Ashur's educational reform ideas. Ibn Khaldun's thinking which tries to initiate logic of thinking with a scientific-religious style becomes the basis for the conception of Islamic education, as well as in building his social theories. Ibn Khaldun's construction of Islamic education thought is very closely related to his perspective in seeing social phenomena that occur in society.[30] This view colors Ibn 'Ashur's mindset.

The concept of malakah with respect to the orientation of malakah (skills) and 'umran (civilization) is one of Ibn Khaldun's thoughts which has a very strong connection with the concept of al-salah al-fardiy and al-salah al-jama'iy Ibn 'Ashur. In which the concept of al'umran is the science of civilization with historical and philosophical explanations which functions to identify religious phenomena that occur, has relevance to the purpose of education in advancing human civilization (Taqaddum al-Hadarah) by realizing individual and social benefit.[31]

The fifth, Ibn 'Ashur also used Greek philosophers as references in building his educational concept. The thoughts of Plato, Socrates, and Aristotle also colored the thinking of islah to Ibn 'Ashur in the education field. This can be seen in the introduction to the book Alaysa al-Subh bi Qarib, in which Ibn 'Ashur quotes Plato's opinion on the characteristics of true education. From Plato's opinion which states that education is instrumental music for the soul and body, and good character "husn al-suluk" is a branch of education. Then at the end of the paragraph, Ibn 'Ashur concludes that the goal of education is the increase in virtue, and this is the main and the most beautiful thing.[32]

\section{Conclusion}

The contribution of Ibn 'Ashur to developing maqasid science is covered in three things, first the thought of Ibn 'Ashur and his contribution in developing maqasid science, 
reintroducing the study of Maqasid al-shari'ah after the stagnation period, developing maqasid al-shari'ah to becomes more holistic (Universal-Partial) and made the study of maqasid an independent science.

There are correlation between the maqasid thoughts of Ibn 'Ashur with interdisciplinary Islamic studies, in which in his four books the science of maqasid is used as an approach in Islamic studies on three themes, namely maqasid science in tafsir studies, educational thought and social society. First, maqasid science in tafsir studies confirmated the validity of tafsir $b i$ al-ra'yi, besides that the exegetical methodology which is based on maqasid, through the book al-Tahrir wa al-Tanwir Ibn 'Ashur also sets the objectives of the al-Qur'an revealed (Maqasid al-Qur'an) as a theory that must be understood by the interpreter in the process of interpreting the quran. Second, maqasid science in educational thought in the concept of Hurriyyah in the sense of freedom in this scientific sense guarantees someone to learn science without the limitations and dichotomy of science. And third, maqasid science in social society in the concept of religion roles to improve the condition of a people which in this case is the subject of change by al-Qur'an.

The factors that influence the thinking of Ibn 'Ashur include; Personal factors of Ibn 'Ashur it self, Environmental factors in which Ibn 'Ashur grows, and external factors that make it intersect with Islamic renewal thinking and in the form of thoughts of reformist figures, sociologists and philosophers.

Acknowledgments. The author is grateful to the Ma'had Aly Hasyim Asy'ari Tebuireng Jombang for providing financial support. 


\section{References}

[1] Mohamad Anang Firdaus, Maqashid al-Syari'ah: Kajian Mashlahah Pendidikan dalam Konteks UN Sustainable Development Goals, JRTIE; Journal of Research and Thought of Islamic Education, Vol. 1, No. 1, pp. 74, August (2018)

[2] Abdurrahman al-Nahlawi, Usul al-Tarbiyah al-Islamiyah, Beirut: Dar al-Fikr, pp. 69-74 (2003)

[3] 'Aishah binti 'Amir ibn 'Uwaimir al-Sufyani. Al-Fikr al-Maqasidi wa Atharuhu fi Bina' alNazariyyah al-Tarbawiyyah al-Islamiyyah. Dissertation Umm al-Qura University, Saudi Arabia, pp. c (2013)

[4] Muhammad al-Tahir al-Misawi. "Al-Shaikh Muhammad al-Tahir ibn 'Ashur wa Qadaya al-Islah wa al-Tajdid fi al-Fikr al-Islami al-Mu'asir: Ru'yah Ma'rifiyyah wa Manhajiyyah”. Jurnal al-Tajdid, Vol. 18. No. 35, pp. 207 (2014)

[5] Naji Faraj al-Takuri. "Malamih al-Islah al-Tarbawi fi Tafsir ibn 'Ashur". Jurnal Usul al-Din. University of al-Asmariya al-Islamiyyah Libia, Vol, 12 No. 01., pp. 61 (2017)

[6] Abd al-Lawi Bashir Makkiy. "Ishkaliyyah Islah al-Ta'lim Min Khilal Alaysa al-Subh bi Qarib li Muhammad al-Tahir ibn 'Ashur". Jurnal Hiwar al-Mutawassitiy, No. 15, Vol. 16, pp. 281-282, March (2017)

[7] Ibn 'Ashur, Maqasid al-Shari 'ah al-Islamiyyah, Amman: Dar al-Nafais, pp. 89 (2001)

[8] Jaser 'Auda, Maqasid al-Shari'ah: A Beginner's Guide. Yogyakarta: Suka Press, pp. 46-48 (2013)

[9] Ibn 'Ashur, Maqasid al-Shari' ah al-Islamiyyah, Amman: Dar al-Nafais, pp. 246 (2001)

[10] Ibn 'Ashur, Maqasid al-Shari' 'ah al-Islamiyyah, Amman: Dar al-Nafais, pp. 273 (2001)

[11] Ibn 'Ashur, Tafsir al-Tahrir wa al-Tanwir, Tunisia: al-Dar al-Tunisiyyah li al-Nashr, Vol 1, pp. 18 (1984)

[12] Ibn 'Ashur, Tafsir al-Tahrir wa al-Tanwir, Tunisia: al-Dar al-Tunisiyyah li al-Nashr, Vol 1, pp. $42(1984)$

[13] Ibn 'Ashur, Tafsir al-Tahrir wa al-Tanwir, Tunisia: al-Dar al-Tunisiyyah li al-Nashr, Vol 1, pp. 30 (1984)

[14] Ibn 'Ashur, Tafsir al-Tahrir wa al-Tanwir, Tunisia: al-Dar al-Tunisiyyah li al-Nashr, Vol 1, pp. 39 (1984)

[15] Belqasim Al Ghali Shaikh al-Jami 'al A'zham, Muhammad Al-Tahir ibn 'Ashur, pp. 152-164.

[16] Ibn 'Ashur, Maqasid al-Shari 'ah al-Islamiyyah, Amman: Dar al-Nafais, pp. 234 (2001)

[17] Ibn 'Ashur, Usul al-Nizam al-Ijtima'iy fi al-Islam, Tunisia: al-Shirkah al-Tunisiyyah li alTauzi', pp. 172-173.

[18] Ibn 'Ashur, Usul al-Nizam al-Ijtima'iy fi al-Islam, Tunisia: al-Shirkah al-Tunisiyyah li alTauzi', pp. 9.

[19] Ibn 'Ashur, Tafsir al-Tahrir wa al-Tanwir, Tunisia: al-Dar al-Tunisiyyah li al-Nashr, Vol 1, pp. 38 (1984)

[20] Ibn 'Ashur, Alaysa al-Subh bi Qarib, al-Ta'lim al-'Araby al-Islamy, Dirasah Tarikhiyyah wa Ara' Islahiyyah, Tunisia: Dar al-Salam Li al-Tiba'ah wa al-Tauzi' wa al-Nashr wa al-Tarjamah, pp. 9 (2006)

[21] Ibn 'Ashur, Alaysa al-Subh bi Qarib, al-Ta'lim al-'Araby al-Islamy, Dirasah Tarikhiyyah wa Ara' Islahiyyah, Tunisia: Dar al-Salam Li al-Tiba'ah wa al-Tauzi' wa al-Nashr wa al-Tarjamah, pp. 9 (2006)

[22] Ibn 'Ashur, Alaysa al-Subh bi Qarib, al-Ta'lim al-'Araby al-Islamy, Dirasah Tarikhiyyah wa Ara' Islahiyyah, Tunisia: Dar al-Salam Li al-Tiba'ah wa al-Tauzi' wa al-Nashr wa al-Tarjamah, pp. 9 (2006)

[23] Ibn 'Ashur, Alaysa al-Subh bi Qarib, al-Ta'lim al-'Araby al-Islamy, Dirasah Tarikhiyyah wa Ara' Islahiyyah, Tunisia: Dar al-Salam Li al-Tiba'ah wa al-Tauzi' wa al-Nashr wa al-Tarjamah, pp. 9 (2006) 
[24] Amin Abdullah, "Islam dan Modernisasi Pendidikan di Asia Tenggara: Dari Pola Pendekatan Dikotomis-atomistik kearah integratif-interdisiplinary", International Conference of Southeast Asian Nations, Universitas Gadjah Mada, Yogyakarta, 10-11 December (2004)

[25] Amin Abdullah, "Islam dan Modernisasi Pendidikan di Asia Tenggara: Dari Pola Pendekatan Dikotomis-atomistik kearah integratif-interdisiplinary", International Conference of Southeast Asian Nations, Universitas Gadjah Mada, Yogyakarta, 10-11 December (2004)

[26] Ibn 'Ashur, Alaysa al-Subh bi Qarib, al-Ta'lim al-'Araby al-Islamy, Dirasah Tarikhiyyah wa Ara' Islahiyyah, Tunisia: Dar al-Salam Li al-Tiba'ah wa al-Tauzi' wa al-Nashr wa al-Tarjamah, pp. 7 (2006)

[27] Ibn 'Ashur, Alaysa al-Subh bi Qarib, al-Ta'lim al-'Araby al-Islamy, Dirasah Tarikhiyyah wa Ara' Islahiyyah, Tunisia: Dar al-Salam Li al-Tiba'ah wa al-Tauzi' wa al-Nashr wa al-Tarjamah, pp. 83 (2006)

[28] Ibn 'Ashur, Alaysa al-Subh bi Qarib, al-Ta'lim al-'Araby al-Islamy, Dirasah Tarikhiyyah wa Ara'Islahiyyah, Tunisia: Dar al-Salam Li al-Tiba'ah wa al-Tauzi' wa al-Nashr wa al-Tarjamah, pp. 28-31 (2006)

[29] Ibn 'Ashur, Alaysa al-Subh bi Qarib, al-Ta'lim al-'Araby al-Islamy, Dirasah Tarikhiyyah wa Ara' Islahiyyah, Tunisia: Dar al-Salam Li al-Tiba'ah wa al-Tauzi' wa al-Nashr wa al-Tarjamah, pp. 28-31 (2006)

[30] Ibn Khaldun, Muqaddimah, translated by Ahmadie Thaha, Jakarta: Pustaka Firdaus, pp. 533$534(2000)$

[31] Ibn 'Ashur, Alaysa al-Subh bi Qarib, al-Ta'lim al-'Araby al-Islamy, Dirasah Tarikhiyyah wa Ara' Islahiyyah, Tunisia: Dar al-Salam Li al-Tiba'ah wa al-Tauzi' wa al-Nashr wa al-Tarjamah, pp. 9 (2006)

[32] Ibn 'Ashur, Alaysa al-Subh bi Qarib, al-Ta'lim al-'Araby al-Islamy, Dirasah Tarikhiyyah wa Ara' Islahiyyah, Tunisia: Dar al-Salam Li al-Tiba'ah wa al-Tauzi' wa al-Nashr wa al-Tarjamah, pp. $10(2006)$ 